\title{
Studies Regarding the Influence of some Bioproducts upon the Productivity of Local Populations of Tomato
}

\author{
Gyöngyi SZABÓ, Raluca MICLEA, Maria APAHIDEAN, Carmen PUIA* \\ Faculty of Agriculture, University of Agricultural Sciences and Veterinary Medicine Cluj- Napoca, \\ Romania \\ *Corresponding author: carmen.puia@yahoo.com
}

Bulletin USAMV series Agriculture 72(2)/2015

Print ISSN 1843-5246; Electronic ISSN 1843-5386

DOI 10.15835/buasvmcn-agr: 11738

\begin{abstract}
The bioproducts realised from microorganisms represent a major orientation in the modern agriculture, because are very well tolerated by the leaving creatures and nave no effect on the people. A very important role in plant protection have the bioproducts based on mycorrhizal fungi but also the products based on benefice bacteria. In the experiences were utilized three local populations of tomatoes: Hostáti, Roz and Inimă de bou. The bioproducts Mycosoil and Bactofil used in the experiences have influenced in a positive way the development of the plants but also the production of tometoes. The variety with the high productivity was Inimă de bou in the mycorrhized and Bordeux mixture treated variant.
\end{abstract}

Keywords: tomato, bioproducts, local populations, mycorrhiza.

\section{INTRODUCTION}

The local populations of tomatoes are used only in the households because they were replaced with the new hybrids appeared on the market, which have a higher productivity. The use of the bioproducts in the control of the plant diseases has taken greater proportions lately, when the safe products for humans and environment are much utilized. Products based on Azospirillum, Bacillus, Pseudomonas and Enterobacter have been used for their positive effect on the growth of the plants (Vessay, 2003). A great role in the plant protection play the products based on the mycorrhizal fungi. These microorganisms can form endophyte associations with the host plants and can interact with other microorganisms from the rhizosphere, influencing the growth of the plants, the efficiency and their resistance to diseases (Hermosa Rosa et al., 2012).

\section{AIMS AND OBJECTIVES}

The purpose of this paper was the study of the bioproduct influence in the tomatoes development and the obtaining of tomatoes with better taste and flavour properties, specific for every local population.

\section{MATERIAL AND METHODS}

In the experiences were utilized three local populations of tomatoes: Hostáti, Roz and Inimă de bou. The bioproducts used were a product based on mycorrhizal fungi (Mycosoil-Myco) and a product based on bacterial strains (BactofilBact). Also conventional(conv. Ridomil,Bravo) and Bordeaux mixture(-Bm) treatments were applied. The experiment was made in three replicates and the data was statistically interpreted with the Polifact program. The control variant is unfertilized (unf). 
Tab. 1. The interaction between fertilisation, variety and treatment on the tomato yield $(\mathrm{kg} / \mathrm{pl})$

\begin{tabular}{|c|c|c|c|c|c|c|}
\hline Variety & Treatment & Fertilization & Average yield & $\%$ to control & $\begin{array}{c}\text { Difference to } \\
\text { control }\end{array}$ & $\begin{array}{l}\text { Significance of } \\
\text { the difference }\end{array}$ \\
\hline \multirow{6}{*}{ Hostati } & \multirow{3}{*}{ Conventional } & Unfertilized & 2.98 & 100.0 & 0.00 & Mt. \\
\hline & & Mycosoil & 3.30 & 110.9 & 0.32 & - \\
\hline & & Bactofil & 3.32 & 111.5 & 0.34 & $*$ \\
\hline & \multirow{3}{*}{$\begin{array}{l}\text { Bordeux } \\
\text { mixture }\end{array}$} & Unfertilized & 3.21 & 100.0 & 0.00 & Mt. \\
\hline & & Mycosoil & 3.66 & 113.9 & 0.45 & $*$ \\
\hline & & Bactofil & 4.02 & 125.0 & 0.80 & $* * *$ \\
\hline \multirow{6}{*}{ Roz } & \multirow{3}{*}{ Conventional } & Unfertilized & 3.43 & 100.0 & 0.00 & Mt. \\
\hline & & Mycosoil & 3.91 & 114.1 & 0.48 & $* *$ \\
\hline & & Bactofil & 4.10 & 119.5 & 0.67 & *** \\
\hline & \multirow{3}{*}{$\begin{array}{l}\text { Bordeaux } \\
\text { mixture }\end{array}$} & Unfertilized & 3.09 & 100.0 & 0.00 & Mt. \\
\hline & & Mycosoil & 3.61 & 116.8 & 0.52 & $* *$ \\
\hline & & Bactofil & 3.61 & 116.8 & 0.52 & $* *$ \\
\hline \multirow{6}{*}{ Inimă de bou } & \multirow{3}{*}{ Conventional } & Unfertilized & 3.37 & 100.0 & 0.00 & Mt. \\
\hline & & Mycosoil & 3.74 & 110.8 & 0.36 & $*$ \\
\hline & & Bactofil & 3.92 & 116.1 & 0.54 & $* *$ \\
\hline & \multirow{3}{*}{$\begin{array}{l}\text { Bordeaux } \\
\text { mixture }\end{array}$} & Unfertilized & 3.96 & 100.0 & 0.00 & Mt. \\
\hline & & Mycosoil & 4.67 & 117.9 & 0.71 & $* * *$ \\
\hline & & Bactofil & 4.13 & 104.3 & 0.17 & - \\
\hline $\begin{array}{l}\text { LDS (p 5\%) } \\
\text { LDS (p 1\%) } \\
\text { LDS(p0.1\%) }\end{array}$ & & $\begin{array}{l}0.33 \\
0.46 \\
0.64\end{array}$ & & & & \\
\hline
\end{tabular}

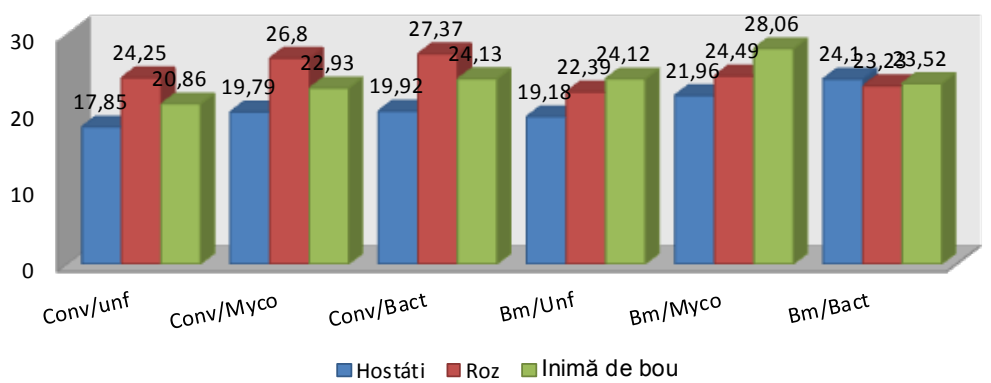

Figure 1. The influence of some bioproducts on the average weights of the tomato fruits (g/fruit)

\section{RESULTS AND DISCUSSION}

The results of the experiments showed that both bioproducts influenced positively the development of the plants, resulting more resistant plants with high yields (Tab. 1), bigger fruits (Fig. 1.) and with specific taste and flavour. The variety with the highest productivity was Inima de Bou which recorded yield of $4.67 \mathrm{~kg} /$ plant in the variant with mycorrhizal and Bordeaux mixture treatment and the lowest productivity was recorded by Hostáti variety with $2.98 \mathrm{~kg} /$ plant in the unfertilized and conventional treated variant (Tab. 1).

\section{CONCLUSION}

From our experiences can be concluded that the application of mycorrhizal fungi and Bactofil treatment influenced in a positive way the productivity of the three populations taken under study.

\section{REFERENCES}

1. Hermosa R, Viterbo A, Chet I, Monte E (2012). Plantbenefical effects of Trichoderma and of its genes, Microbiology, 158: 17-25.

2. Vessay JK (2003). Plant Growth Promoting Rhizobacteria as Biofertilizers, Plant and Soil, 255: 571-586. 